\title{
EVAPORITE KARST IN THE BLACK HILLS, SOUTH DAKOTA AND WYOMING, AND THE OIL PLAY IN THE WILLISTON BASIN, NORTH DAKOTA AND MONTANA
}

\author{
Jack B. Epstein, Daniel H. Doctor \\ U.S. Geological Survey, 12201 Sunrise Valley Drive, MS 926A, Reston, Virginia, 20192, jepstein@usgs.gov, \\ dhdoctor@usgs.gov
}

\begin{abstract}
Subsurface red beds of the Permo-Triassic age Spearfish Formation in the Williston Basin has recently been touted as "another Bakken Oil Boom for North Dakota". The senior author, totally uninformed about the subsurface geology of North Dakota, was requested by INFOCAST* to discuss petroleum potential in the Spearfish based on his field experience in the outcrop belt of the Black Hills in neighboring Wyoming and South Dakota. That request was extended to a discussion of the surface and subsurface evaporite-karst features in four formations ranging from Pennsylvanian to Jurassic age. Dissolution of these rocks, which has resulted in sinkholes, caves, springs, breccia pipes, and subsurface collapse, has apparently gone on since the Black Hills was formed during the Early Tertiary, and continues today. The formation of salt-dissolution paleokarst in the Williston Basin and adjacent Powder River Basin has been documented to have occurred many times in the geologic past, between the mid-Paleozoic through the Tertiary. Reported subsurface collapse has affected rock characteristics, including local structure, fracturing, porosity, and permeability. These significant effects of evaporite karst in the Williston Basin, as well as in subsurface evaporite-bearing sequences nationally, should be of concern to any oil exploration efforts, as well as for surface infrastructure development such as pipeline right-of-way.
\end{abstract}

\section{Introduction}

Large areas of the United States are underlain by evaporite deposits that mainly consist of gypsum, anhydrite, and salt (Figure 1). Holocene dissolution has created abundant karstic features at the surface and near-surface in many areas. Dissolution has also occurred during intervals in the geologic past, thereby creating many intervals of paleokarst throughout Paleozoic-lower Mesozoic-age strata in the Rocky Mountains and adjacent mid-western United States.
Many of the evaporite intervals lie within or between petroleum-bearing horizons, and karstic development within them are of concern to oil and gas exploitation. In this paper we discuss two areas of interest: 1) surficial evaporite karst in the Black Hills of Wyoming and South Dakota, and its extension into the subsurface in the Williston Basin of North Dakota, and 2) a paleokarst horizon in the upper Madison Limestone of Wyoming and South Dakota, and its possible extension into the Williston Basin.

Oil and gas potential in the Williston Basin of North Dakota and adjacent Saskatchewan, Canada, has recently attracted considerable attention, with particular interest in the organic shales of the Bakken Formation of Devonian age. With the use of hydraulic fracturing to increase the release of oil and gas from these source rocks, other stratigraphic units in the basin, such as the Spearfish Formation of Permian and Triassic age, have been touted as possibly being additional unconventional oil plays in the subsurface of North Dakota (LeFever, 2011). In contrast to the reducing environment of deposition of the dark organic-rich rocks in the Bakken, the Spearfish is a red-bed sequence deposited in an oxidizing environment. The Spearfish has been prospected in northernmost North Dakota, more than 500 km (340 $\mathrm{mi}$ ) from the nearest outcrops in the northern Black Hills (Figure 2). It is not exposed at the surface in North Dakota, so one of us (Epstein) was requested to discuss the geologic characteristics of that formation in its nearest outcrop belt of the northern Black Hills of South Dakota and Wyoming.

\section{The Spearfish Formation and evaporite karst in the Black Hills}

The Black Hills is an asymmetric uplift about $210 \mathrm{~km}$ (130 mi) north-south and $100 \mathrm{~km}(60 \mathrm{mi})$ east-west. It is cored by Precambrian age metamorphic rocks that are

*http://www.infocastinc.com/downloads pdf/bakken 11 pre.pdf (accessed 11/5/2012) 


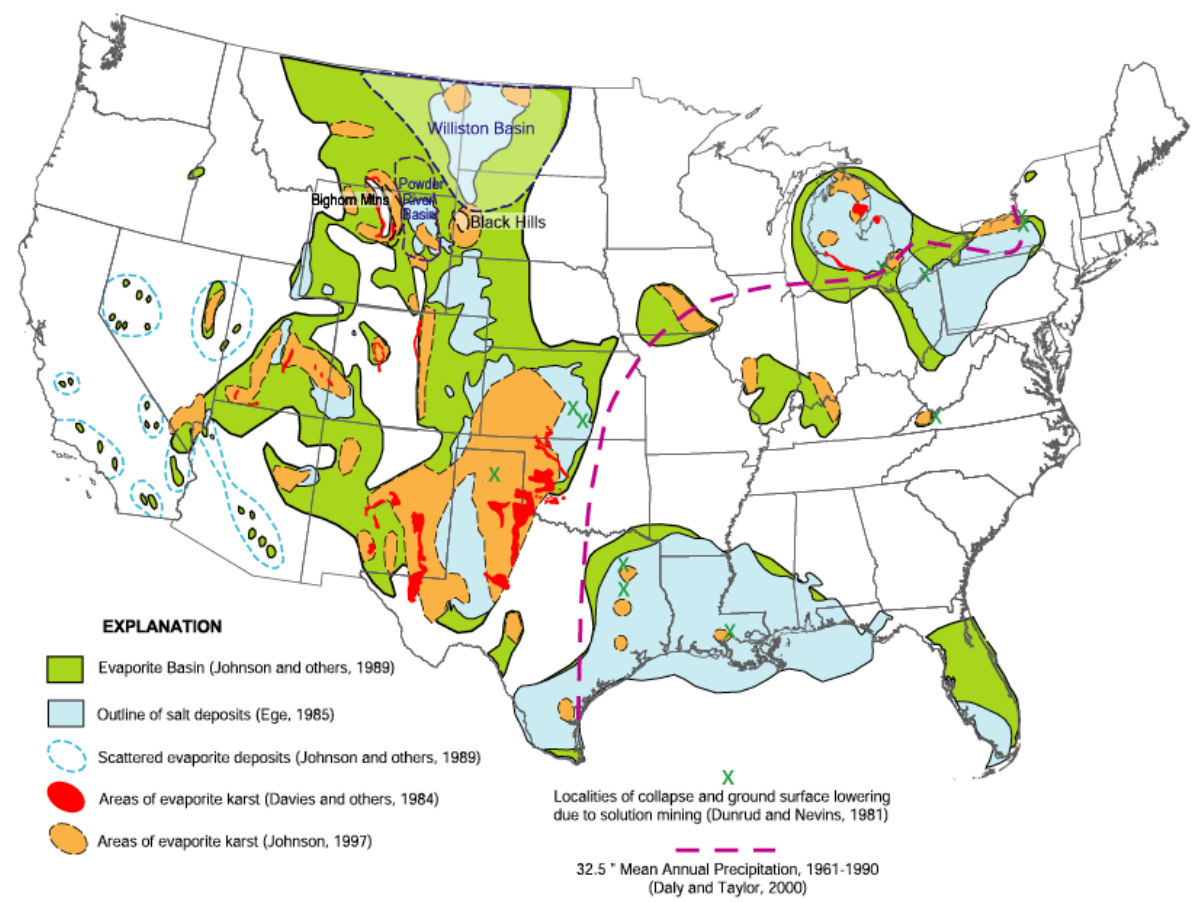

Figure 1. Map showing the distribution of outcropping and subsurface evaporite rocks in the United States and areas or reported evaporite karst. The 32.5-in. mean-annualprecipitation line approximates a diffuse boundary between eastern and western United States karst terrains (from Epstein and Johnson, 2003).

surrounded by shallow-marine to nearshore terrestrial sedimentary rocks of Paleozoic and Mesozoic age which dip away from the center of the dome (Figure 3). Gypsum and anhydrite are found in rocks ranging in age from Mississippian to Jurassic (Figure 4). The "Limestone Plateau" located outbound from the central Black Hills core, comprises rocks of the Madison Limestone (Pahasapa Limestone of other reports) and the Pennsylvania age Minnelusa Formation. Most surface exposures of the Minnelusa contain abundant karst features resulting from dissolution of anhydrite at depth. The Madison contains brecciated rocks resulting partly from similar gypsum dissolution, as well as world-class limestone caves. The "Red Valley" encircles the Black Hills resulting from the erosion of siltstones, shales, and gypsum in the Spearfish Formation. Resistant sandstone of Cretaceous age forms the hogback that encircles the Black Hills and defines its outer physiographic perimeter. Below those sandstones is a thin gypsum bed in the Gypsum Spring Formation of Jurassic age. Much of the information about the karst in the Black Hills presented here is summarized from Epstein (2003) and Epstein and others (2005).

The Spearfish Formation in the Black Hills ranges to slightly more than $240 \mathrm{~m}(800 \mathrm{ft})$ in thickness, consisting predominantly of red, planar-bedded and laminated shale, siltstone, and very fine-grained sandstone, with interbedded gypsum abundant at varying horizons (Figure 5). Bedding is generally sheet-like, although lenticular beds and ripple laminations are not uncommon. Salt casts have been reported (Sabel, 1984). These sedimentary features indicate that the Spearfish was deposited in a hot and arid climate on low-gradient coastal plains and nearshore hypersaline mudflats bordering evaporite basins.

Sinkholes are abundant in the northern Black Hills. They range in size from small shallow pits and solutionallywidened joints (Figure 6) of as little as several feet to as much as much as $140 \mathrm{~m}$ (460 ft) across (Figure 7). The Vore Buffalo Jump shown in Figure 7 is rimmed by several convoluted, disjoined, and disrupted gypsum beds $2.5-3.0 \mathrm{~m}(10 \mathrm{ft})$ thick. No gypsum is seen at the bottom of the sinkhole, which is probably less than $15 \mathrm{~m}$ $(50 \mathrm{ft})$ above the underlying Minnekahta Limestone. The Minnekahta crops out along the service road about one

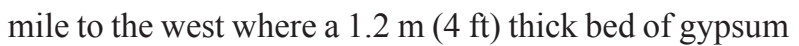
lies at the base of the Spearfish (Figure 8).

The largest sinkhole in the northern Black Hills is about $140 \mathrm{~m}(460 \mathrm{ft})$ across, occurs at the base of the 


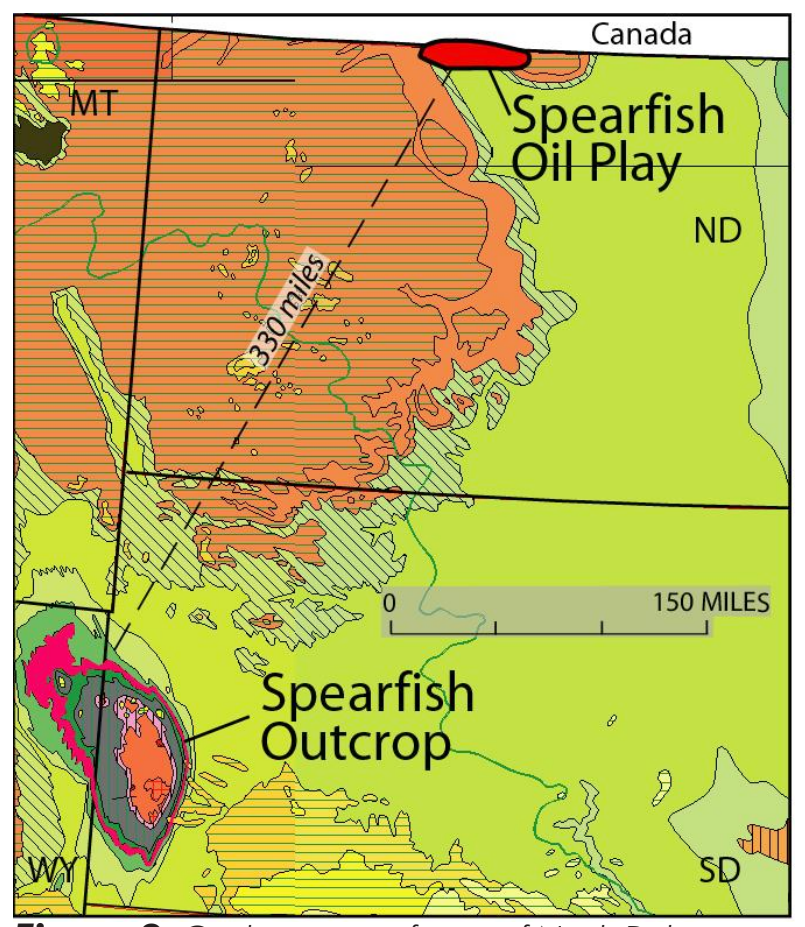

Figure 2. Geologic map of parts of North Dakota, South Dakota, Wyoming, and Montana. The outcrop area of the Spearfish Formation in the Black Hills is located approximately $530 \mathrm{~km}$ (330 mi) from the Spearfish oil play in Bottineau County, North Dakota. The Black Hills is a domal structure cored by Precambrian rocks in the center (orange). It is encircled by uplifted and erosionally breached Paleozoic to Cretaceous rocks. Red beds and evaporite deposits of the Spearfish Formation (red) form a valley nestled between the hogback of Cretaceous age sandstones and plateau of underlying carbonate rocks, including the Madison Limestone of Mississippian age. The surface rocks in the western part of North Dakota are dominated by Tertiary rocks (solid green) overlying Cretaceous sediments to the west.

Spearfish Formation (Figure 8). It is underlain by a 1.2 $\mathrm{m}(4 \mathrm{ft})$ thick bed of gypsum which in turn overlies the Minnekahta Limestone; both dip gently underneath the sinkhole. The limestone outcrop closest to the sinkhole contains a small collapse opening in a blind valley. A smaller sinkhole (inset of Figure 8) opened in 1985, and was observed by local ranchers who heard running water in a cavern that extended horizontally beyond the limits of their flashlight beam (Ted Vore, oral communication, 1999). This running water at the base of the Spearfish is deemed to be partly responsible for dissolution and collapse. However, the four-foot-thick gypsum bed in the basal Spearfish seems to be too thin to account for all the observed depth of the collapse.

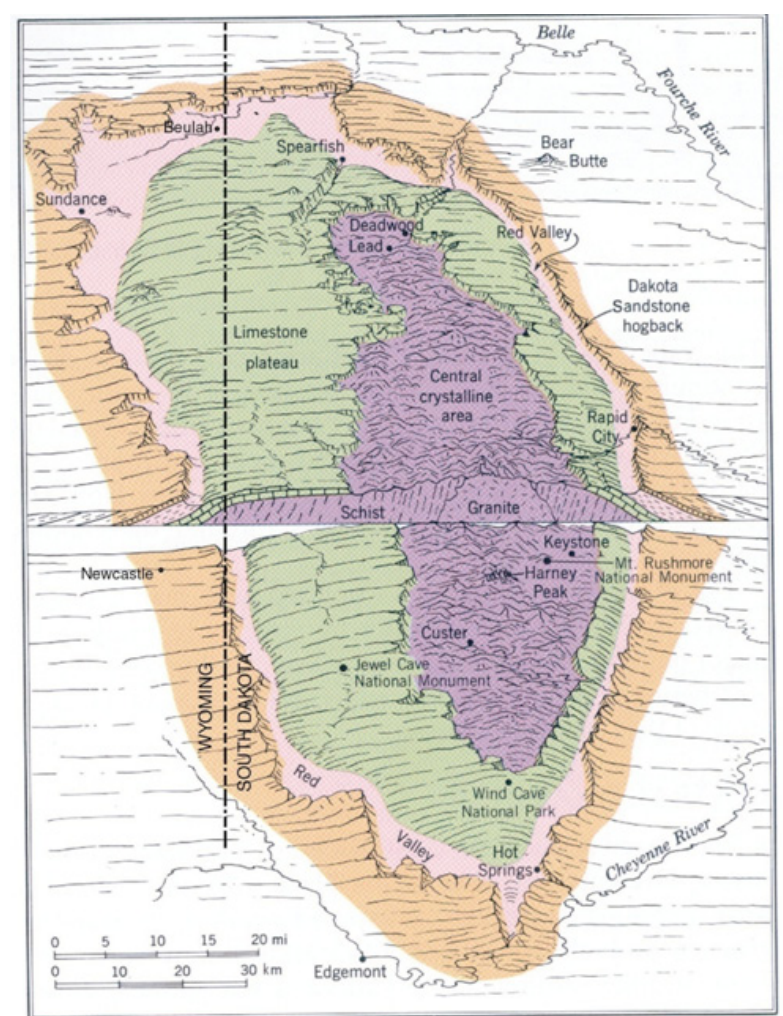

Figure 3. Generalized diagram showing the geology and geomorphology of the Black Hills, Wyoming and South Dakota. Modified from Strahler and Strahler (1987), with permission.

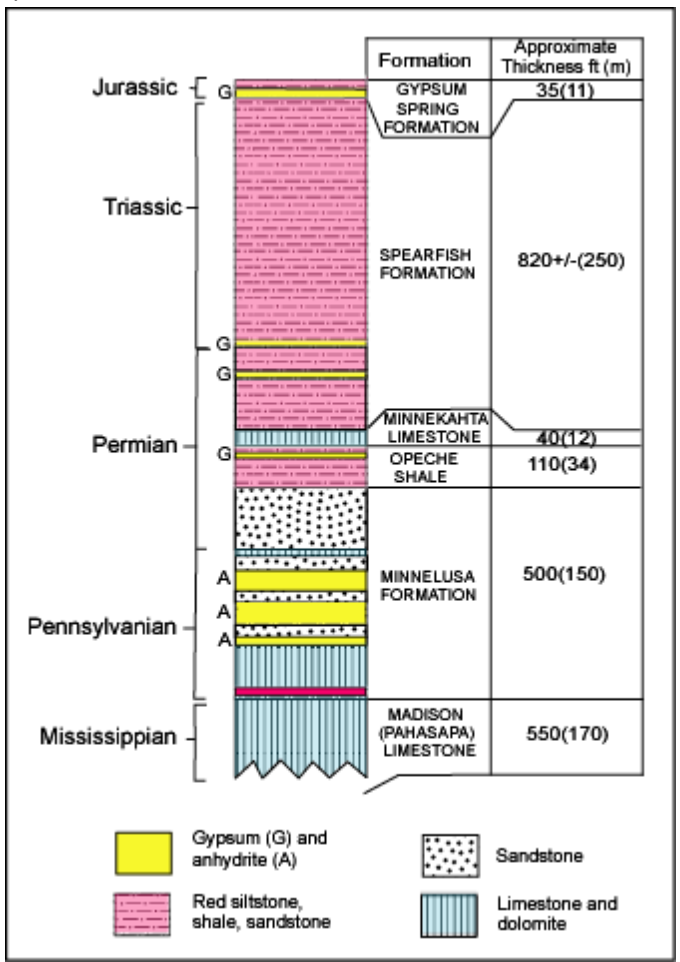

Figure 4. Stratigraphic column showing distribution of gypsum and anhydrite in the northern Black Hills. 
Figure 5. Typical exposures of the Spearfish Formation in the Black Hills, South Dakota and Wyoming. (A) White gypsum interbedded with red shale and siltstone about $15 \mathrm{~km}$ (10 mi) southeast of Newcastle, Wyoming. (B) Planar-bedded red beds overlain by shales of the Stockade Beaver Member of the Sundance Formation (dashed line), one mile northeast of Beulah, Wyoming. A bed of gypsum, about $3 \mathrm{~m}$ (10 ft) thick, comprising the entire Gypsum Spring Formation a few miles to the east of this locality, is missing here. This is the closest exposure of the

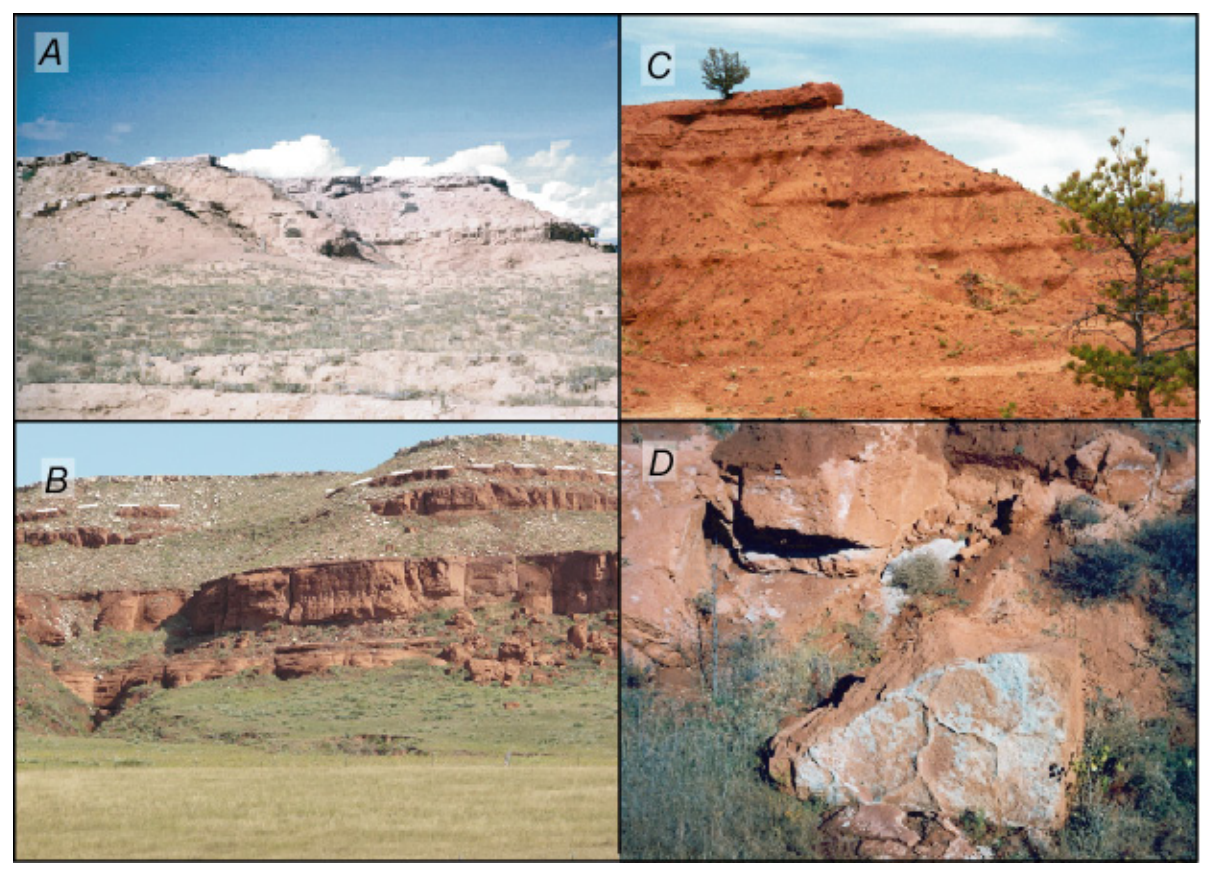
Spearfish Formation to the Spearfish oil play in northern North Dakota. (C) Fining-upward sequences of very fine-grained sandstone, siltstone and shale in Devil's Tower National Monument, Wyoming. (D) Spearfish mudcracks $73 \mathrm{~km}$ (8 mi) northwest of Spearfish, South Dakota.

The Spearfish Formation in the northern Black Hills is as much as $250 \mathrm{~m}(820 \mathrm{ft})$ thick and contains several intervals of gypsum in the lower $60 \mathrm{~m}$ (200 ft). Anhydrite, which probably was the original form of calcium sulfate to be deposited in the Spearfish, undergoes about a 40 percent expansion when hydrated to form gypsum. As a result, the gypsum is commonly highly folded (Figure $9 A, B)$. It also becomes mobile, being injected into irregular fractures as thin veinlets, generally less than 2 $\mathrm{cm}(1$ in) wide in the confining beds above and below

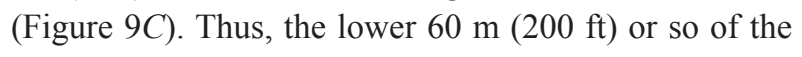
Spearfish has developed a secondary fracture porosity resulting in appreciable ground water flow into water

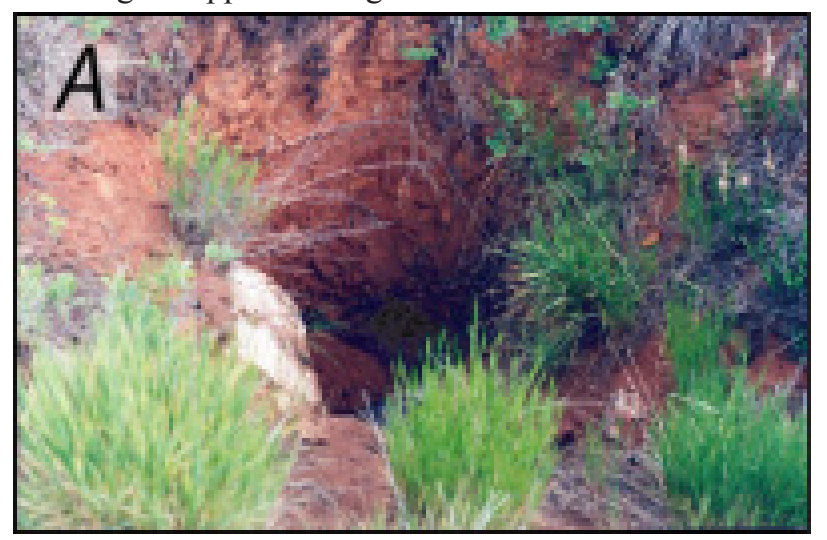

wells. Perched water tables with springs below zones of gypsum in fractured red beds are present in several places in the Black Hills. Gypsum beds are lacking in the upper $180 \mathrm{~m}(600 \mathrm{ft})$ of the Spearfish. Therefore, bedding is not disturbed by gypsum expansion, and the interval is a confining layer.

Breccia pipes are common in the Black Hills, including in the Spearfish Formation (Figure 10). These pipes consist of chaotic blocks in a matrix of rocks of the enclosing formations and they commonly extend below the base of the Spearfish. The large sinkholes in the lower Spearfish shown in Figures 7 and 8 contain

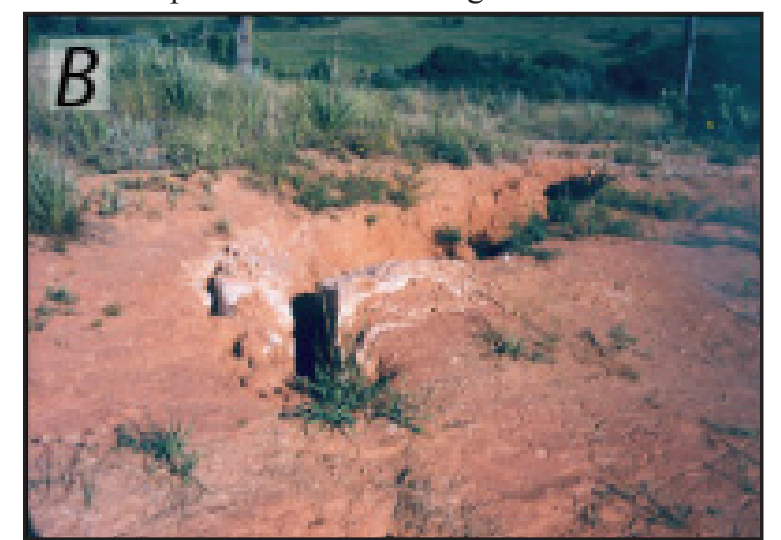

Figure 6. Small solution openings near Beulah, Wyoming.

(A) Circular sinkholes about one meter across, with remnant gypsum present in thebottom.

(B) Soil collapse along a solution-widened joint that extends downslope towards a creek. 


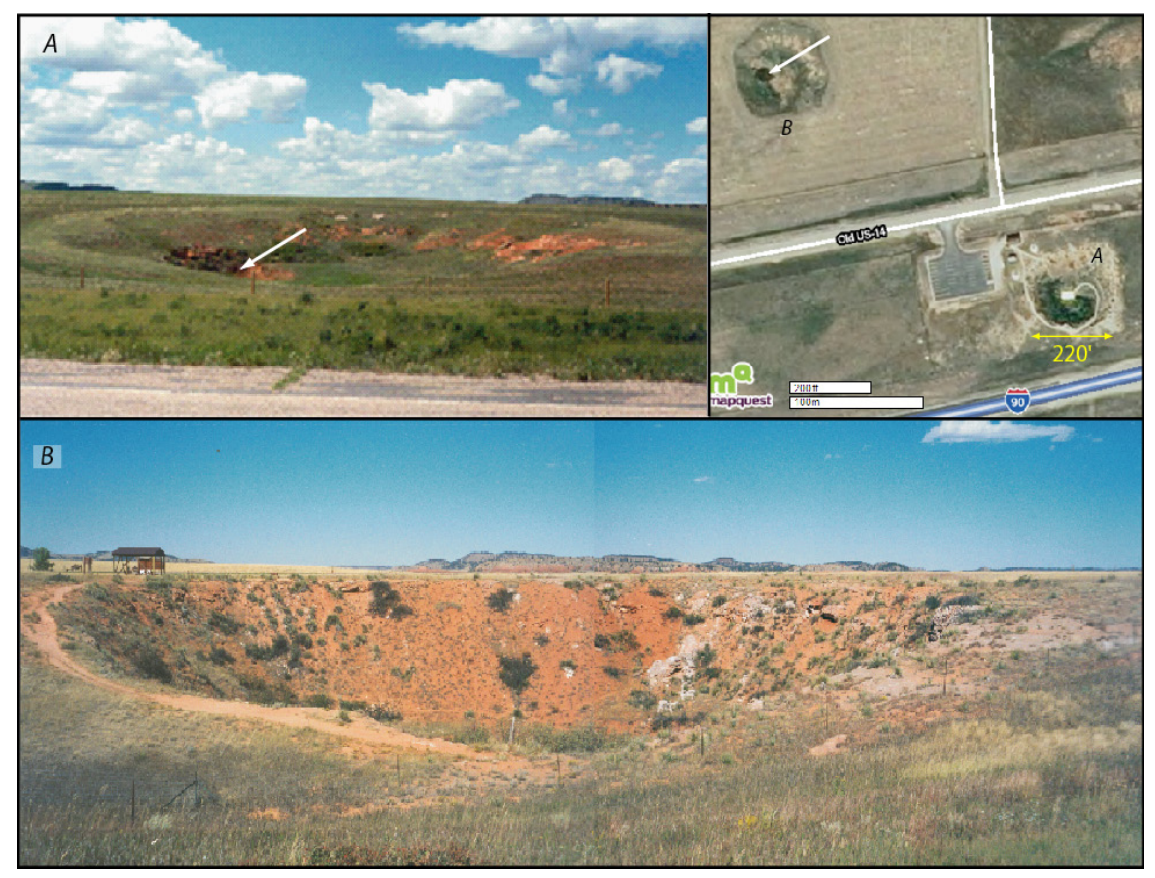

Figure 7. Two sinkholes located $5.6 \mathrm{~km}$ (3.5 mi) west of Beulah, Wyoming, and immediately north of Interstate 90. (A) Sinkhole with a laterforming smaller internal sinkhole at arrow. (B) The "Vore Buffalo Jump" is an 18-m (60 ft)-foot deep sinkhole. More than 300 years ago the Native Americans stampeded bison over the steep rim into the hole. As many as 20,000 beasts were butchered for food. The site is now a major archeological dig by the University of Wyoming (http:// www.vorebuffalojump.org Accessed 11/13/2012/).

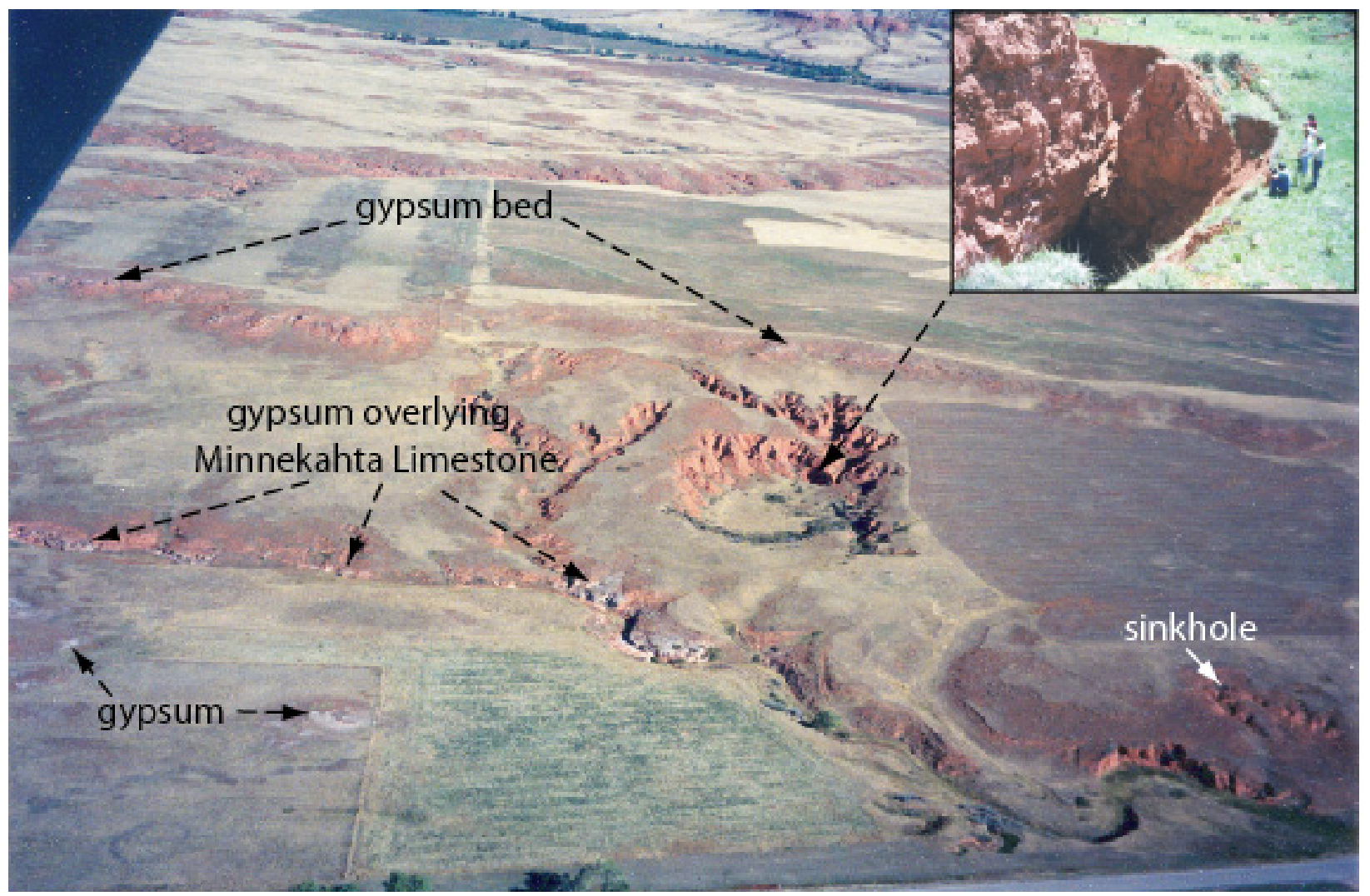

Figure 8. Karst features located immediately northwest of the Vore Buffalo Jump shown in figure 7. A deep sinkhole (see inset photo) lies within a larger, $740 \mathrm{~m} \mathrm{(460} \mathrm{ft)} \mathrm{wide,} \mathrm{flat-bottom} \mathrm{sinkhole} \mathrm{in} \mathrm{center} \mathrm{of} \mathrm{the} \mathrm{photo.}$ Another sinkhole lies in the lower right corner. A conspicuous gypsum bed lies immediately above the Minnekahta Limestone and also underlies the sinkholes. Another gypsum bed lies above and to the north of the sinkholes. 


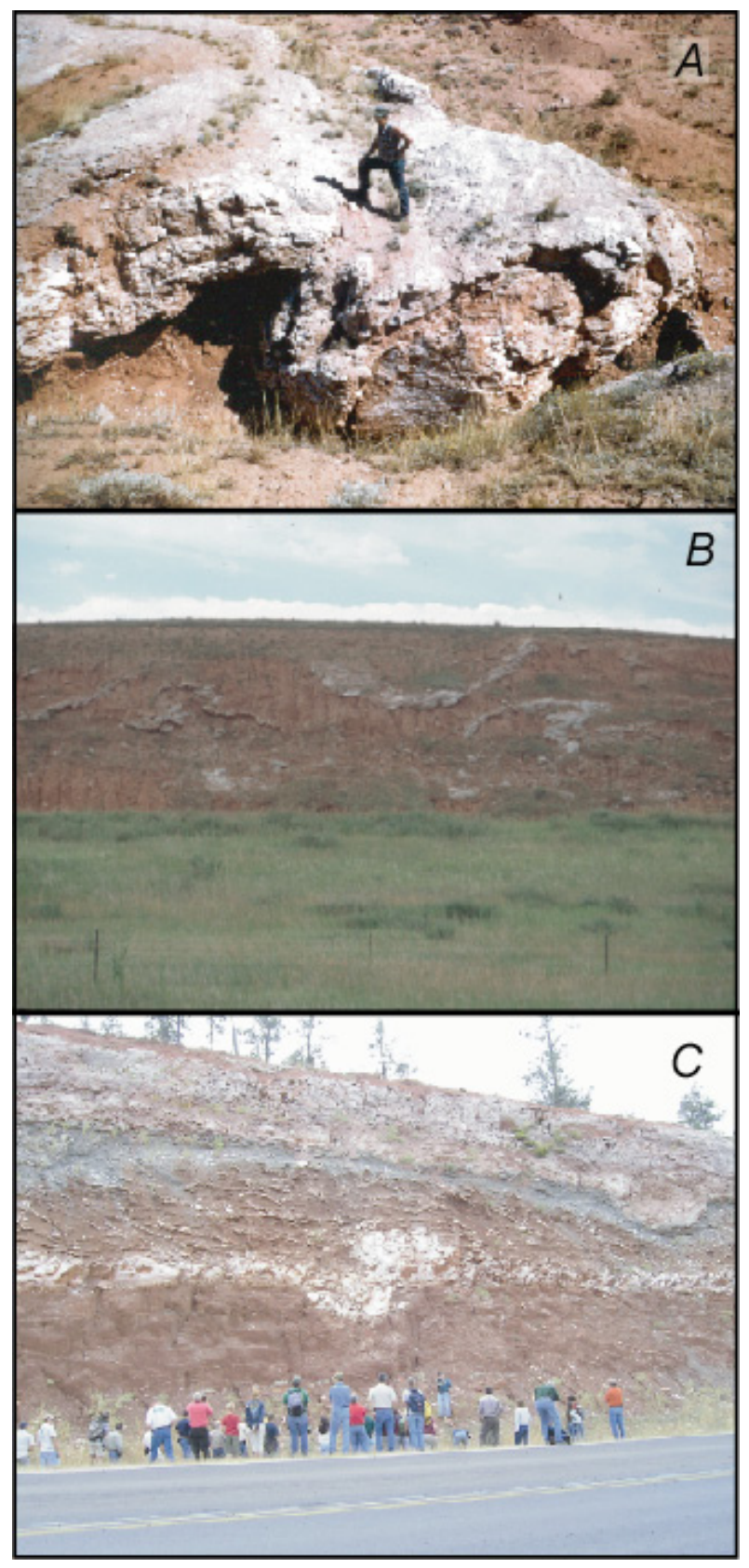

Figure. 9. (A) Contorted gypsum resembling tectonic folds in the Spearfish Formation, Red Valley of the southwestern Black Hills, southeast of Newcastle, Wyoming, resembling tectonic folds. (B) Disrupted gypsum near Beulah, Wyoming. (C) Gypsum-filled fractures extending above and below contorted gypsum bed in the uppermost Spearfish Formation, along State Route 71 about $15 \mathrm{~km}$ (9 mi) southwest of Hot Springs, South Dakota.

some gypsum interbedded with the red beds. However, the bottom of the sinkhole is near or at the base of the formation, suggesting that the solution collapse is not

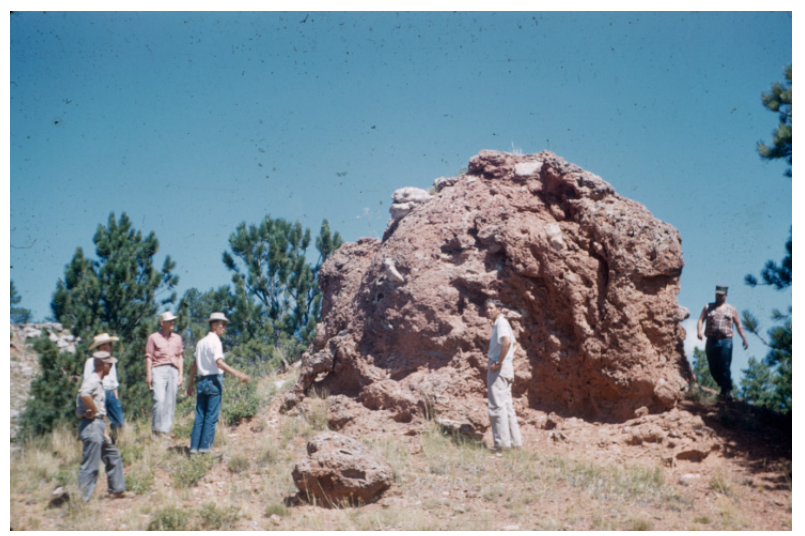

Figure 10. Resistant pinnacle-forming breccia pipe in the Spearfish Formation, about $24 \mathrm{~km}$ (15 mi) west of Hot Springs, South Dakota. The breccia pipe occurs about $100 \mathrm{~m}$ above the dissolved anhydrite in the Minnelusa Formation. Some sandstone clasts were derived from the overlying Sundance Formation, more than $30 \mathrm{~m}$ (100 ft) above.

entirely the result of dissolution of the local gypsum, but additionally due to removal of evaporites at greater depth.

The top of the Minnelusa Formation lies about 45 m (150 $\mathrm{ft}$ ) below the base of the Spearfish Formation. It is about $150 \mathrm{~m}(500 \mathrm{ft})$ thick in the northern Black Hills and consists of dolomite, sandstone, and shale with anhydrite being prevalent in the middle part. The anhydrite is mostly absent in outcrops due to removal by solution in the subsurface. The solution of anhydrite and consequent formation of voids in the Minnelusa at depth resulted in foundering and fragmentation of overlying rocks, thereby producing extensive disruption of bedding, a regional collapse breccia, many sinkholes, and breccia pipes and pinnacles (Figure 11). The collapse breccia consists of angular clasts of all the local rock types in a sandy matrix that is generally cemented with calcium carbonate. The vuggy secondary porosity of the collapse breccia, along with the porous sandstone makes the upper half of the Minnelusa an important aquifer in the Black Hills.

Proof that collapse subsidence extended upward from the Minnelusa into the Spearfish is afforded by collapse observed within the thin intervening Minnekahta Limestone as seen near the sinkholes in Figures 7 and 8. Along Redwater Creek the Minnekahta is exposed in a $600 \mathrm{~m}(2000 \mathrm{ft})$ low cliff where numerous sinkholes are present and the unit is extensively brecciated, and the underlying Opeche Shale is also disrupted (Figure 12). This observation suggests that collapse structures in the Minnelusa extend upward through the Opeche and Minnekahta into the Spearfish. 


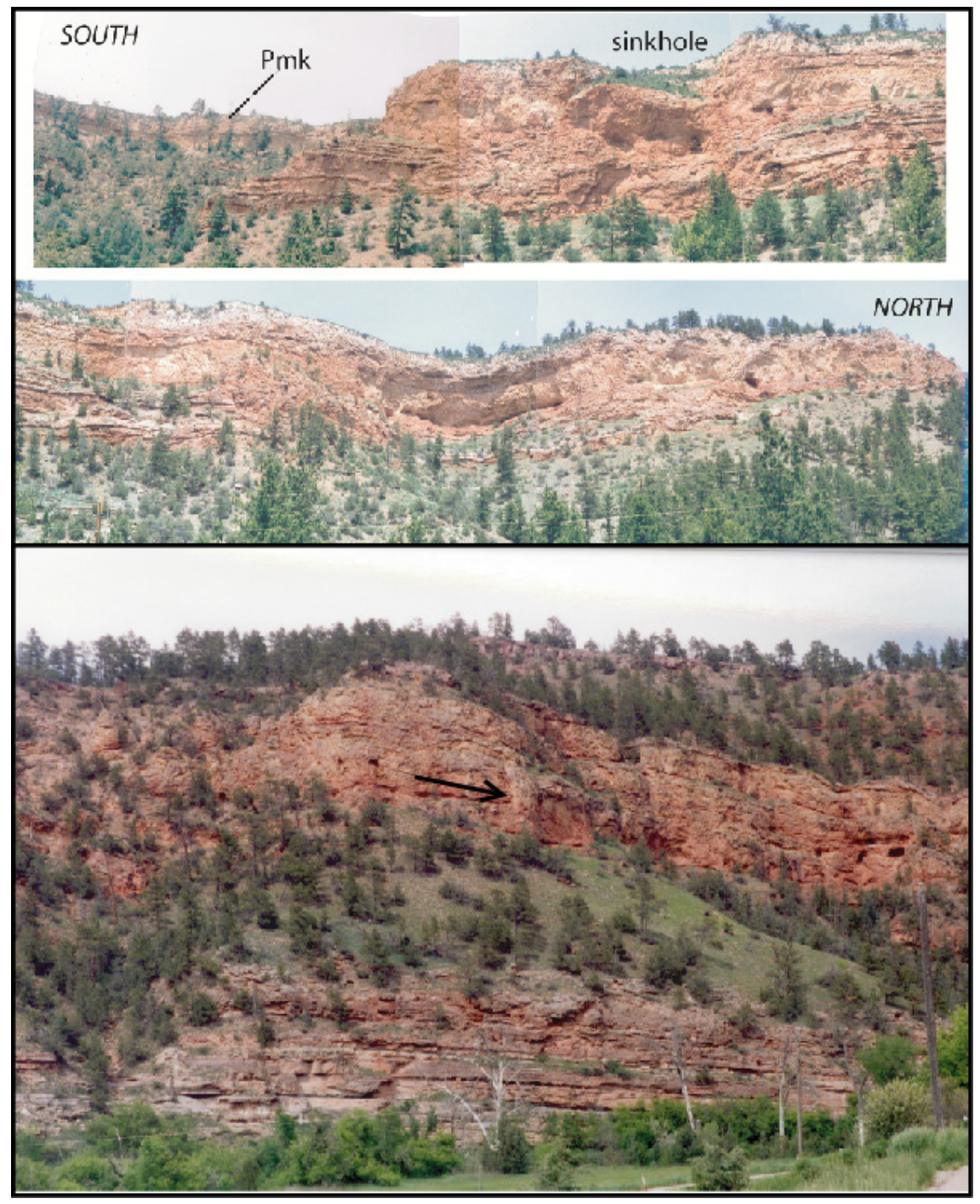

Figure 11. Collapse

structures in the Minnelusa

Formation. Top photo is

split into two segments at

the dashed match line,

showing the upper half of

the Minnelusa Formation in

Redbird Canyon, South Dakota,

$16 \mathrm{~km}(10 \mathrm{mi})$ southeast of

Newcastle, Wyoming. All

beds are disrupted and mostly

brecciated. Sinkholes and

caves dot the canyon wall.

Bottom photo shows Cold

Brook Canyon, just west of Hot

Springs, South Dakota. The

upper half of the formation is

brecciated with through-going

breccia pipes (arrow). The

lower half of the formation is

not brecciated. Collapse was

due to removal of many tens

of meters of anhydrite in the

subsurface prior to exposure

of the canyon wall within the

covered slope in the middle of

the photo.

While breccia pipes and sinkholes may extend upward from the Minnelusa Formation into overlying formations, the evidence also suggests that sinkholes in the Spearfish may not necessarily be directly connected to pipes in the underlying Minnelusa. Abundance of sinkholes in the lower Spearfish suggests that there lurks a labyrinth of cavernous passageways developed as gypsum dissolved at the base of the formation while collapse extended upwards into the underlying Minnekahta Limestone.

Figure 13 shows the suggested systemic development and relationships of surface and subsurface karst features within and between the Minnelusa Formation, Opeche Shale, Minnekahta Limestone, and Spearfish Formation in the Black Hills. Groundwater in all units is generally under artesian-flow conditions. Groundwatr dissolution of subsurface anhydrite in the Minnelusa, as well as in the underlying Madison Limestone, has caused collapse features in the Minnelusa, commonly seen on canyon walls. Breccia pipes and some sinkholes have extended upwards into rock at least $120 \mathrm{~m}$ (400 ft) above the Spearfish. Local extensive disruption in the Minnekahta precedes groundwater flow along the gypsum in the basal Spearfish, creating the sinkholes in that formation. Karst development evolved continuously after the Black Hills was uplifted and exposed to erosion since the Late Cretaceous/Early Tertiary. Artesian groundwater conditions result from direct infiltration of rainfall and snow melt at high altitudes of the central Black Hills which flow outward and downdip through the rimming sediments, including the Madison and Minnelusa. Dissolution and removal of the anhydrite in the Minnelusa, progresses in a downdip direction 


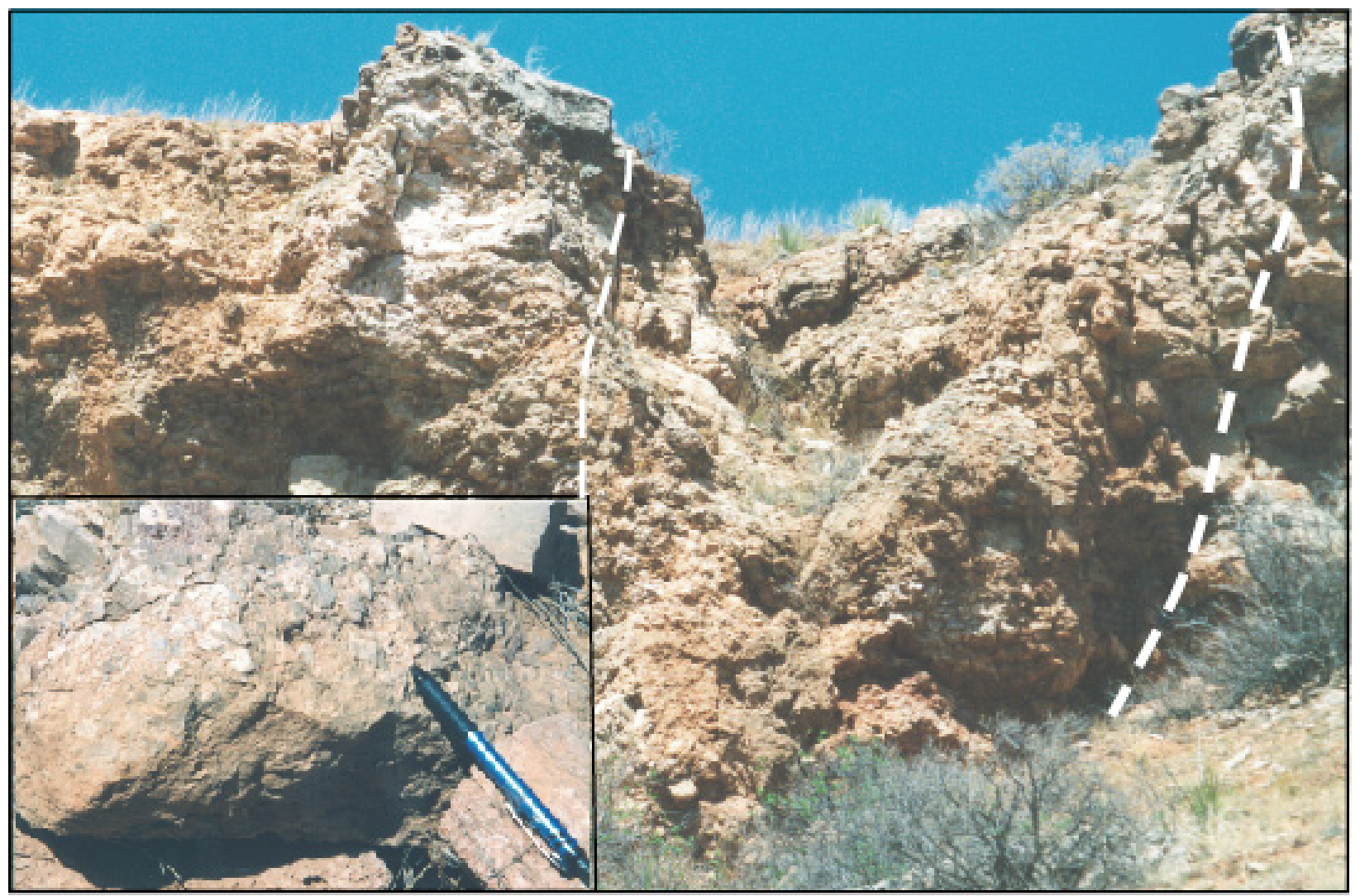

Figure 12. Collapse sinkhole (between dashed line) in a zone of brecciated Minnekahta Limestone, along Redwater Creek, $1.6 \mathrm{~km}$ (1 mi) southeast of the sinkholes seen in Figure 7. Inset shows details of the breccia.

with groundwater flow resulting in collapse breccias, breccias pipes, and resurgent springs that are developed at the site of (Figure 14).

As the Black Hills region is slowly lowered by erosion of the anhydrite-dissolution front in the subsurface, the Minnelusa moves downdip and radially away from the center of the uplift. As a result, resurgent springs will dry up and new ones will form with the downdip migration of the dissolution front as the geomorphology of the Black Hills evolves (Figure 14). Abandoned sinkholes on canyon walls (Figure 11) attest to the former position of the dissolution front. Groundwater has dissolved the anhydrite in the Minnelusa, but it is present in the subsurface, therefore a transition zone must be present where dissolution of anhydrite is currently taking place. Consequences of this model suggest that present resurgent springs will eventually cease to flow while new springs should develop in a downdip direction within the regional hydraulic gradient of the Black Hills. Solution of anhydrite in the Minnelusa probably began soon after the Black Hills was uplifted in the Early Tertiary, and it continues today.

\section{Paleokarst in the Madison Group}

The Charles Formation, which forms the upper part of the largely limestone and dolomite succession of the Madison Group, contains a remarkable intrastratal paleokarst. This stratigraphic interval is particularly well-exposed within the canyon of the Bighorn River in eastern Wyoming (Figure 15). It has an areal distribution extending across the Williston Basin in North Dakota and far to the southwest into the Bighorn Basin of Wyoming and Montana (Figure 16; Peterson, 1987; Sando, 1995). In the Black Hills, this paleokarst horizon is exposed within numerous cave systems such as Wind Cave and Jewel Cave. This extensive intrastratal paleokarst horizon contains abundant evaporite strata - mainly anhydrite and gypsum. Geologic studies of this interval show that it formed from groundwater migration and solution of evaporite minerals in an artesianflow system not unlike what has been documented to occur today in the western Black Hills. Collapse brecciation of cavernous solution voids has since been filled with finegrained silt and clay that is cemented with late calcite cement (Palmer and Palmer, 2008). Characteristics of this paleokarst horizon are similar to those described above for the Minnelusa Formation in the Black Hills. 


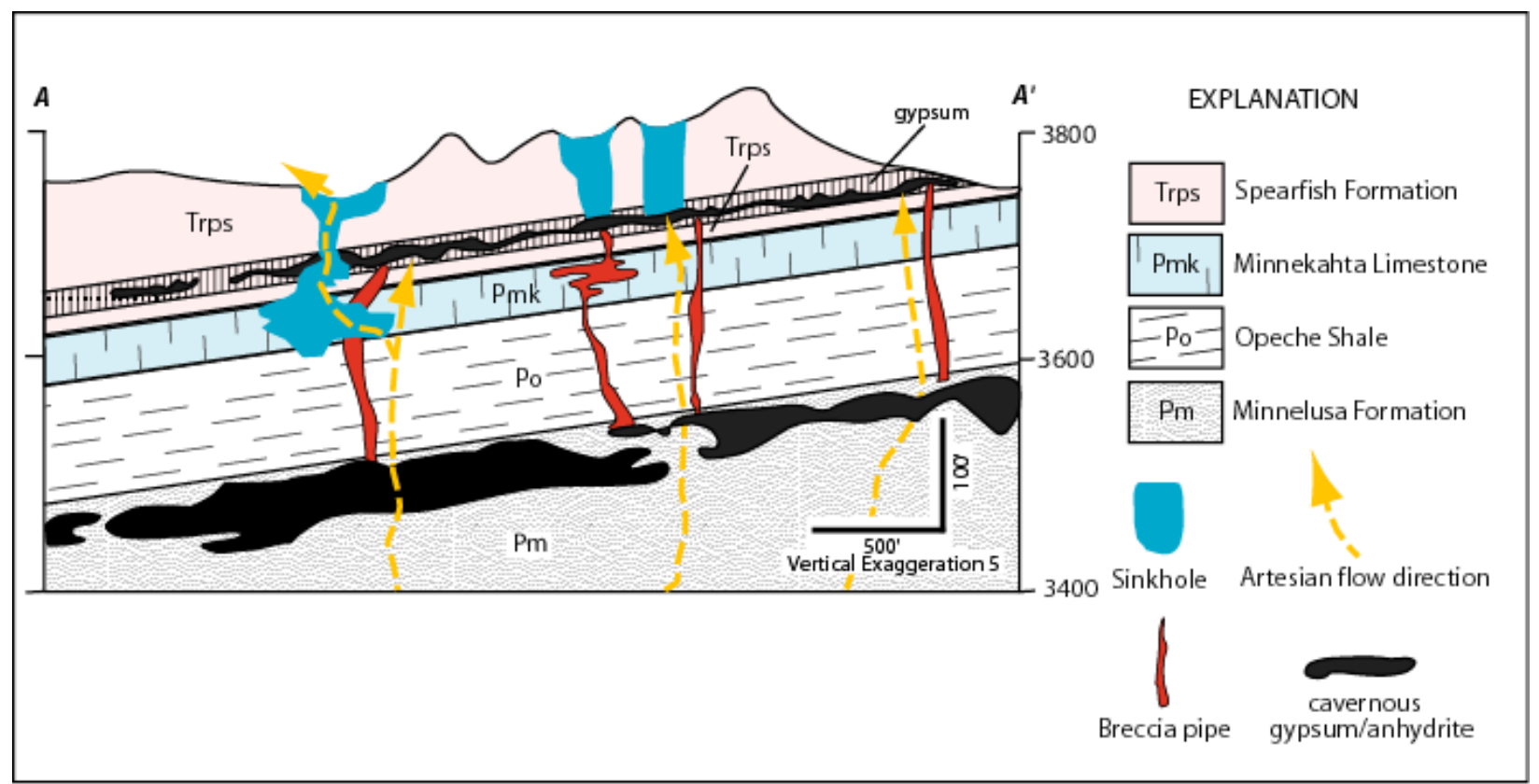

Figure 13. Generalized cross section showing common karst features in the Beulah area, Wyoming. Features include sinkholes, cavernous gypsum in the basal Spearfish Formation, outcropping sinkholes in the Minnekahta Limestone, breccia pipes and dissolution zone at the top of the Minnelusa Formation, and artesian flow direction from the Minnelusa Formation and the Madison (Pahasapa) Limestone. Where the potentiometric surface is below ground level, sinkholes are dry; where it is above ground level, sinkholes contain emergent springs.

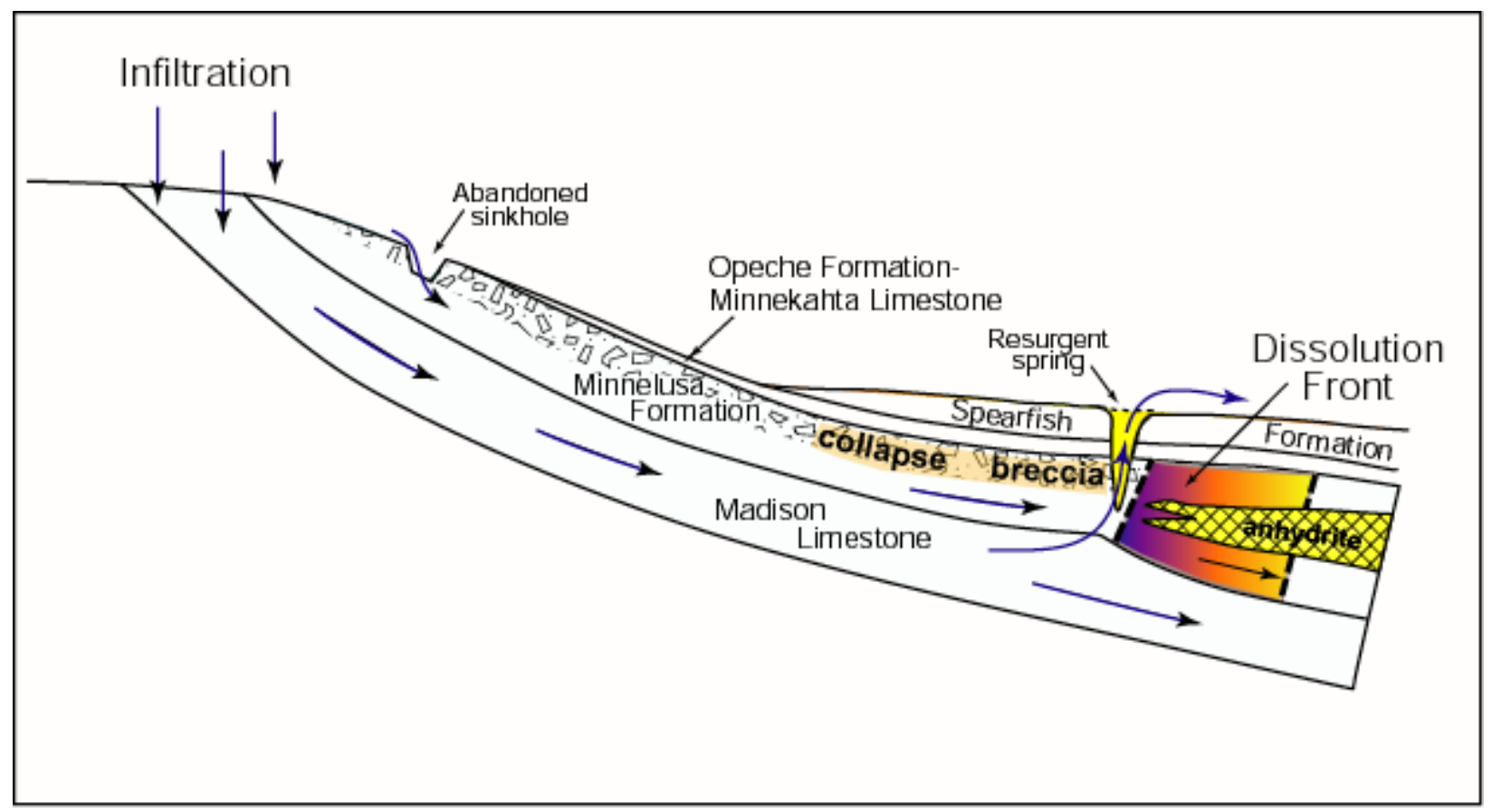

Figure 14. Generalized cross section showing the downdip migration of the anhydrite dissolution-front in the Minnelusa formation. Cox Lake and other resurgent springs are near the position of the dissolution front. As the front moves downdip with continued solution of the anhydrite, and as the Black Hills is slowly lowered by erosion, these sinkholes and related collapse structures are left abandoned on canyon walls (see Figure 3). 

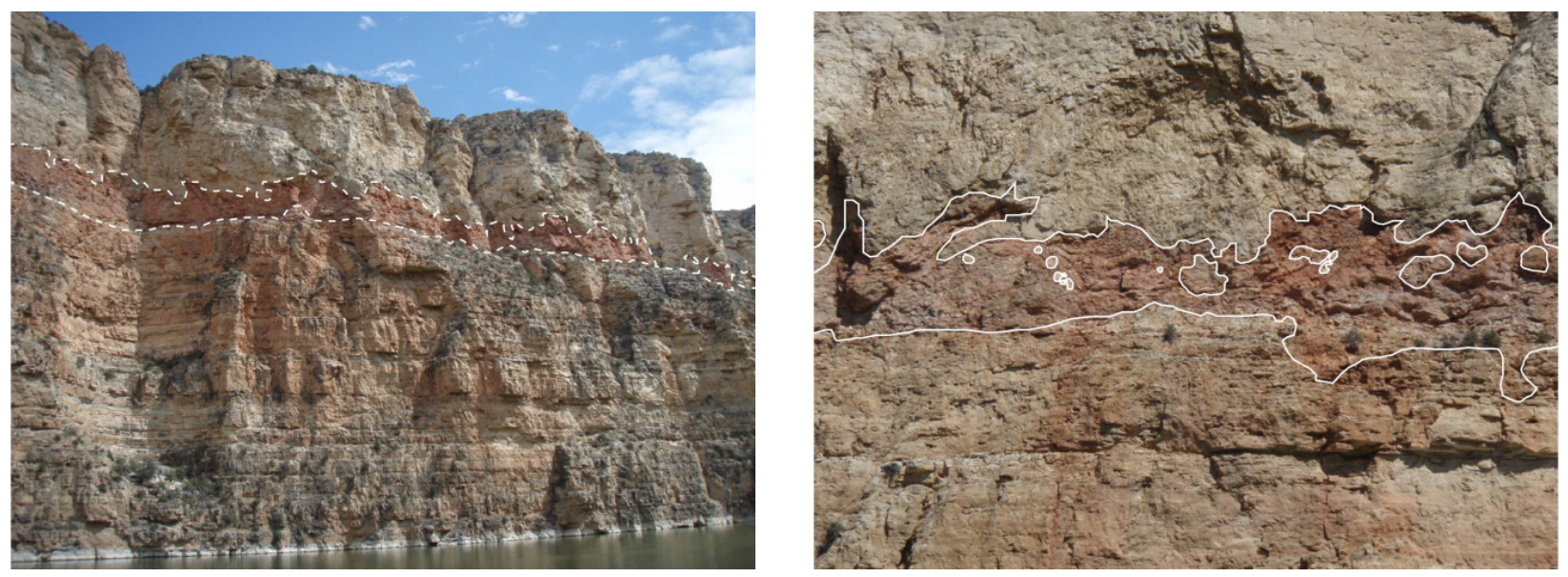

Figure 15. Exposure of paleokarstic breccia due to evaporite dissolution in the upper Madison Limestone. Exposure is within the Bighorn Canyon in eastern Wyoming. The outlined reddish layer contains abundant brecciated clasts of dolomite with vugs of anhydrite and gypsum. The red matrix is fine silt and clay cemented with late calcite. Layer thickness varies between 3 to $6 \mathrm{~m}$ (10 to $20 \mathrm{ft}$ ).

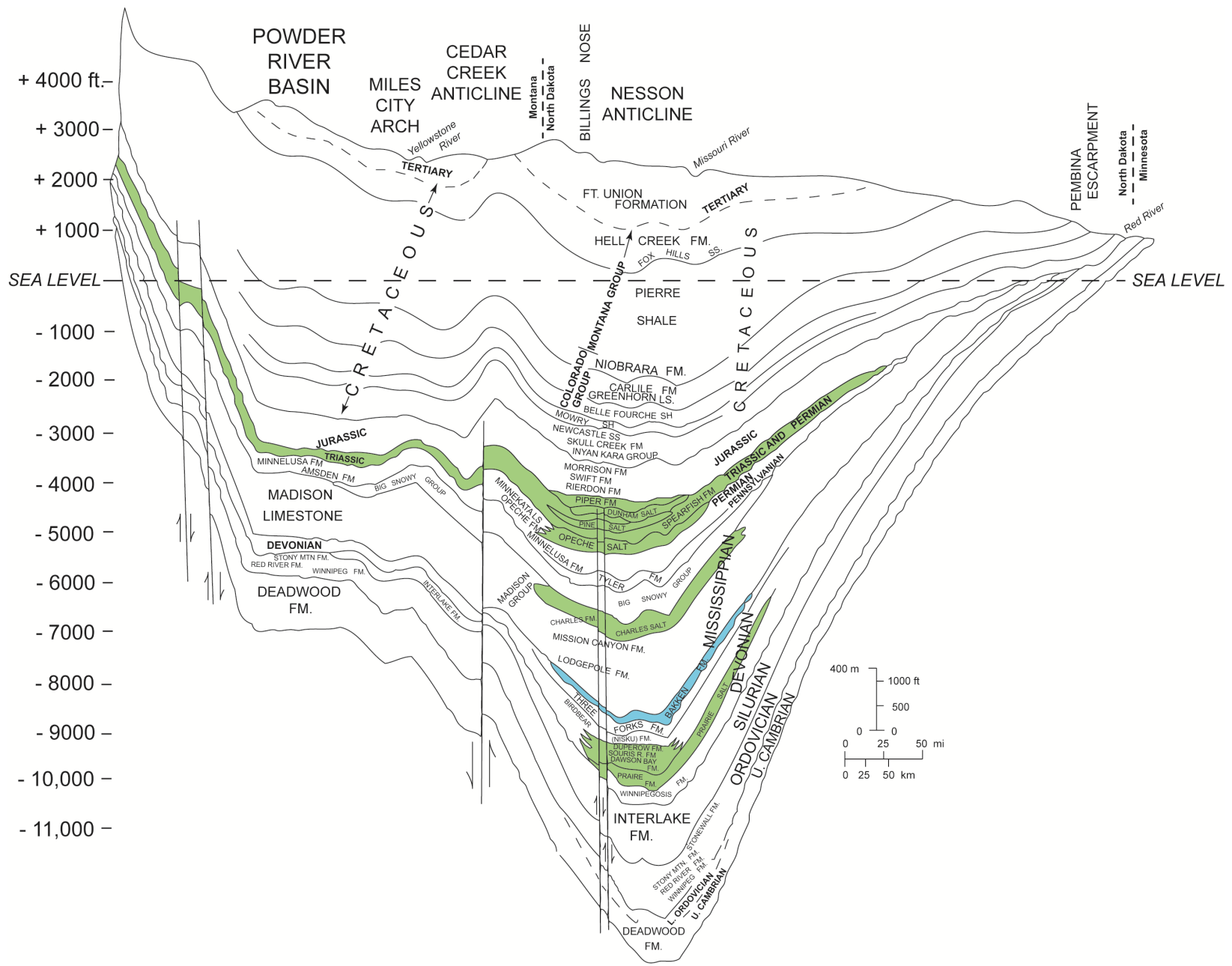

Figure 16. Generalized west-east structural stratigraphic cross section from the Bighorn Mountains, Wyoming, to north-eastern North Dakota. Modified from Peterson, 1988. Green color indicates units with significant evaporites, especially salt (compare with Figure 17). Blue color indicates the Bakken Formation. 
The presence of this paleokarst horizon in the Madison Group suggests that the processes forming surficial karst today due to evaporite solution at depth have occurred multiple times in the geologic past within these evaporitebearing rocks. Exposures of such ancient solutioncollapse features can provide insight for understanding possible geologic structures and characteristics within deeply buried evaporite horizons that are experiencing solution in the Williston Basin.

\section{Salt dissolution in the Williston Basin}

The Williston Basin is a large intracratonic structural downwarp in North Dakota and eastern Montana, extending into Canada, and lying immediately north of the Black Hills of Wyoming and South Dakota (Figure 1). Deposition was intermittently continuous since the Middle Cambrian, with a total accumulation of about 4,900 m (16,000 ft) of sediment (Gerhard et al., 1990). Sedimentation rate kept pace with basin subsidence rate, so deposition mainly occurred in shallow water and in recurring evaporite basins. Transgressive and regressive cycles are numerous; pinchouts and disconformities are abundant (Peterson and MacCary, 1987, Figure 5). More than a dozen periods of evaporite deposition characterize the stratigraphic section (Figure 17). LeFever and LeFever (1995) recognized 24 major and minor salt beds within the basin. In contrast to the rocks in the Black Hills, halite and potash salts are common. The transition from salt in North Dakota to anhydrite, gypsum, and minor interbedded dolomite in many Black Hills formations marks the boundary between North Dakota evaporite basins to a shelf/sabkha environment in South Dakota and Wyoming.

Peterson (1995) presented a stratigraphic chart showing the occurrence of 12 hydrocarbon source beds and 15 reservoir rocks in the Williston Basin.

In the Williston Basin evaporites are commonly interbedded with petroleum source rocks. These evaporites may form seals and traps, or their karstic effects may disrupt stratigraphic continuity and disrupt the integrity of a reservoir. Subsurface dissolution features similar to those in the Black Hills has been documented in the Williston and nearby Powder River Basins. Bachu and Hitchon (1996, p. 253) noted the high salinity of formation waters, due partly to dissolution by fresh water in many of the Paleozoic aquifers.

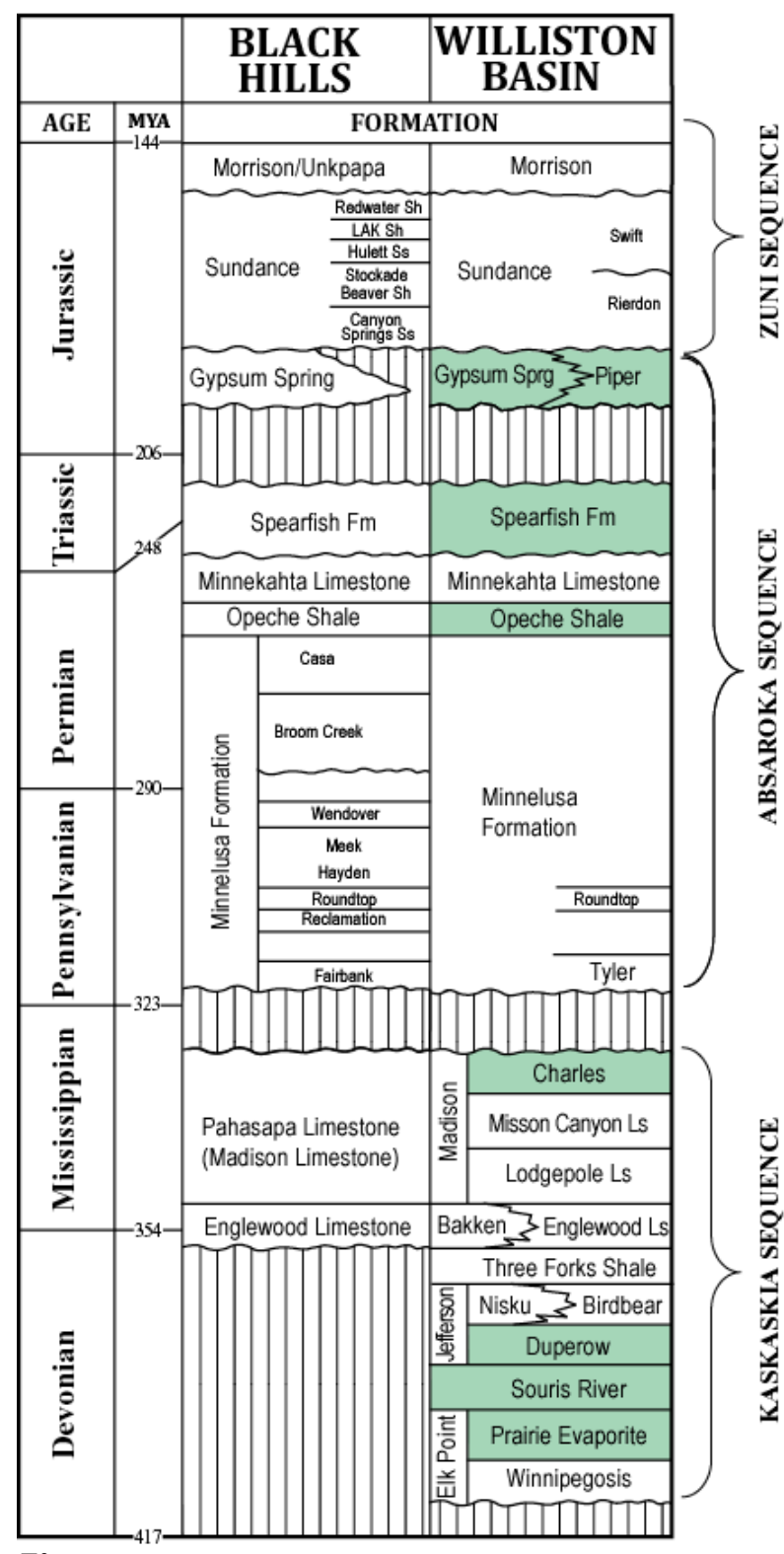

Figure 17. Chart comparing the Devonian-Jurassic stratigraphy in the Black Hills, South Dakota, and Williston Basin, North Dakota. Formations with significant evaporites, especially salt, and some with more than one horizon, are in green (compare with Figure 16). Modified from Fahrenbach and others, 2010. See also: figure 1 in LeFever (2012); figure 2 in Burrus and others (1996); and figure 4 in Peterson (1988).

The modern regional flow path of formation waters is generally towards the east and northeast, emanating from the recharge areas in the Bighorn and Big Snowy Mountains and the Central Montana uplifts and Black Hills: a somewhat similar pattern to that shown in Figure 14 (Bachu and Hitchon, 1996, Figure 10). 
Salt thickness throughout the Williston Basin locally can be quite variable in thickness, apparently related to uneven dissolution due to several factors. Salt dissolution can be recognized by comparing thinning of salt in isopach maps in relation to overlying thicker compensating sediments that filled in the resulting hollow. The irregular thickness of the Dunham Salt in the Jurassic age Piper Formation occurs in isolated lenses due to dissolution (LeFever and LeFever, 1995). They also noted significant thicknesses of salt in the subsurface Spearfish Formation in the southwest corner of North Dakota. No salt is exposed at the surface in the Black Hills, although salt is known in springs along Salt Creek about $14 \mathrm{KM}$ (8.5 mi) north of Newcastle, Wyoming, along US 85. At this location a roadside sign indicates that Darton, in 1904, determined that salt comprised 5 percent of the water there; about four percent salt was reported by Brobst and Epstein (1963). During the late 1800's significant quantities of salt were produced by evaporation. Whether that salt comes from the Minnelusa or the Spearfish is not known, but it does show that evaporite dissolution in the subsurface is ongoing.

The thickness of the Spearfish Formation in the northern Black Hills, close to the North Dakota border, varies from 190 to $268 \mathrm{~m}$ ( 625 to $879 \mathrm{ft})$ in water wells within the borders of two 7.5-minute quadrangles (Epstein, J.B., unpub data). This suggests that the gypsum, and possibly unrecognized salt, has been removed to create the discrepancy. Parker (1967) noted similar salt-thickness variations within short distances in several different units, such as the Middle Devonian Prairie Formation and Permian and Triassic age rocks of the Minnelusa Formation, Opeche Shale, and Goose Egg Formation ( Spearfish).

Several authors have recognized a slow-moving dissolution front that reduced the original depositional boundary of an individual salt deposit, such as in the Jurassic age Piper Formation (LeFever and LeFever (1995). Seismic data was used by Hamid and others (2004) to delimit the southern margin of evaporite in the Middle Devonian Prairie Formation, which is very complex due to dissolution removal of salt and brecciation.

A correlation exists between of areas of salt dissolution and the presence of faults and fractures that extend down into the Precambrian basement, and that were reactivated in the Paleozoic. These faults allowed fluid to move up into the salt bed from aquifers below. Salt removal was also intermittent, generally with long periods of no perceptible dissolution (Parker, 1967; Holter, 1969; LeFever and LeFever, 1995).

Holter (1969) identified solution-collapse breccias in cores in the Prairie Formation in Saskatchewan by the very poor sorting of angular rock fragments. The material in the lower part of the brecciated units are fine grained, apparently a residue from salt solution. Breccia deposits extend laterally beyond the present limits of salt, suggesting a migrating salt front as dissolution progresses in the direction of fluid flow. Dissolution of evaporites (salt) in the Williston Basin requires a hydrostatic head that allows ground water to dissolve and carry the salt in solution upwards, as well as tectonically induced fractures to tap fresh-water aquifers below the salt (Parker, 1967). Breccia pipes (dissolutioncollapse structures (filled stopes and chimneys)) may have formed along the edges of salt-dissolution fronts, extending vertically upward from several salt horizons and terminating at various unconformity horizons (Burke, 2001). If breccia pipes can be identified in the Williston Basin, they could be the locus for upwardflowing water as well as hydrocarbons. They may also affect the porosity of surrounding rocks by either creating solution voids or depositing cements. Breccia pipes in the Minnelusa of the Black Hills have high permeability and have been described as pathways for uranium-rich fluids (Gott and others, 1974). Breccia pipes in the Black Hills are also known to extend more than $300 \mathrm{~m}(1,000$ $\mathrm{ft}$ ) upwards from their source beds in the Minnelusa, suggesting considerable vertical interconnection in the sedimentary succession.

Subsurface solution collapse can affect important rock characteristics for petroleum development, such as fracturing, porosity, and permeability. Several studies have linked the dissolution of the thick Silurian to Jurassic age salt deposits in the Williston Basin to petroleum reservoir development. Salt and evaporite dissolution can also form stratigraphic and unconformity traps (LeFever, 2011, 2012) and salt collapse, halite plugging, incomplete anhydrite or residue seals, and dolomitization have affected or destroyed potential reservoirs (LeFever and LeFever, 1995).

The age of salt dissolution may be determined by the age of overlying sedimentary deposits that have been thickened due to in-filling of downwarps due to salt 
removal and collapse. Using this criteria Parker (1967) described the age of salt dissolution in different units in the subsurface of Wyoming, North Dakota, and Montana: Late Devonian through Mississippian for the Middle Devonian age Prairie Formation, and a Jurassic age for the Minnelusa Formation, Opeche Shale, and Goose Egg Formation.

Rasmussen and Bean (1984) concluded that the salt in the Ervey Member of the Goose Egg Formation in the Powder River and Williston Basins was removed by dissolution in Middle-Late Jurassic and Early Cretaceous time. Fractures extending from the basement controlled movement of groundwater and solution. Orchard (1987) showed that salts in the Mississippian age Charles Formation pinches out abruptly and are mostly missing over the Poplar Dome in the western part of the Williston Basin of Montana, while non-salt beds are continuous and exhibit little change in thickness. He attributed this to removal of the uplifted salt by ascending water along fractures that developed during Tertiary Laramide uplift. LeFever and LeFever (1995) concluded that the irregularities in thickness of the Pine Salt in the Spearfish Formation in the southwestern half of the basin were caused by dissolution during the Late Jurassic-Early Cretaceous and may have been similarly affected during the Late Cenozoic. LeFever (2011) also noted numerous times of salt removal in the Devonian Prairie Formation, including Middle and Late Devonian, Mississippian through Jurassic, pre-Cretaceous, and even Late Pleistocene to Recent.

\section{Conclusions}

Dissolution of gypsum and anhydrite in several stratigraphic units in the Black Hills, South Dakota and Wyoming, has resulted in development of a variety of both modern and paleo-karst features, including regional collapse breccias, breccia pipes and pinnacles, sinkholes, and extensive disruption of bedding. Evidence of recent collapse includes fresh scarps surrounding shallow depressions, recently formed sinkholes, and sediment disruption and contamination in water wells and springs. Anhydrite dissolution in the Minnelusa Formation probably dates back to the Early Tertiary when the Black Hills uplift commenced, and it continues today as an anhydrite dissolution-front in the subsurface Minnelusa moves downdip and radially away from the center of the Black Hills uplift. Over time, sinkholes and artesian springs associated with the migrating dissolution front will dry up and new ones will form as the geomorphology of the Black Hills evolves. Abandoned sinkholes and breccia pipes that are preserved in cross section on canyon walls attest to the former position of the dissolution front. The Spearfish Formation, mostly comprising red shale and siltstone, has developed secondary fracture porosity due to considerable expansion during the hydration of anhydrite to gypsum. Many of the evaporite-karst features that are readily visible in the Black Hills have also been reported or suggested in the subsurface Williston Basin, including collapse breccias, breccia pipes, sinkholes (solution depressions), and progressive salt-margin retreat along a dissolution front. Petroleum geologists contemplating the effects of salt karst in the oil patch in North Dakota would do well to examine the excellent karst exposures in the Black Hills of South Dakota and Wyoming. As an additional thought, a better understanding of the distribution of karst-controlled surface-collapse features in the Black Hills would be helpful in planning interstate pipeline routes from the expanding oil fields in North Dakota.

\section{References}

Bachu S, Hitchon B. 1996. Regional-scale flow of formation waters in the Williston Basin. American Association of Petroleum Geologists Bulletin 80 (2): 248-264.

Brobst DA, Epstein JB. 1963. Geology of the Fanny Peak quadrangle, Wyoming-South Dakota. U.S. Geological Survey Bulletin 1063-1. p. 323-377.

Burke RB. 2001. Some aspects of salt dissolution in the Williston Basin of North Dakota. North Dakota Geological Survey Newsletter 28 (1): 1-5.

Burrus J, Osadetz KG, Wolf S, Doligez B, Visser K, Dearborn D. 1996. A two-dimensional regional basin model of Williston Basin hydrocarbon systems: American Association of Petroleum Geologists Bulletin 80: 265-291.

Davies WE, Simpson JH, Ohlmacher GC, Kirk WS, and Newton EG. 1976. Map showing engineering aspects of karst in the United States, U.S. Geological Survey Open-file Report, OFR 76-0623, 1 sheet, 1:750,000,000 scale.

Daly C, Taylor G. 2000. United States average annual precipitation, 1961-1990: Spatial Climate Analysis Service, Oregon State University; USDA -NRCS National Water and Climate Center, Portland, Oregon; USDA -NRCS National Cartography and Geospatial Center, Fort Worth, Texas; Available from: http://www.ftw.nres.usda.gov/prism/prismdata.html 
Dunrud CR, Nevins BB. 1981. Solution mining and subsidence in evaporite rocks in the United States, U.S. Geological Survey Miscellaneous Investigation Series, MI-1298, 2 sheets.

Ege JR. 1985. Maps showing distribution, thickness, and depth to salt deposits of the United States: U.S. Geological Survey Open-File Report 85-28, 11 p., 4 plates.

Epstein JB, Johnson KS. 2003. The need for a national evaporite-karst map. In: Johnson, KS, Neal JT, editors. Evaporite Karst and Engineering/Environmental Problems in the United States. Oklahoma Geological Survey Circular 109. p. 21-30.

Epstein JB. 2003. Gypsum karst in the Black Hills, South Dakota-Wyoming: Geomorphic development, hazards, and hydrology. In: Johnson, KS, Neal JT, editors. Evaporite karst and engineering/environmental problems in the United States. Oklahoma Geological Survey Circular 109. p.241-254.

Epstein JB, Davis AD, Long AJ, Putnam LD, Sawyer JF. 2005. Field Trip 2, Karst field trip to the northern Black Hills. In Kuniansky EL, ed., U.S. Geological Survey Karst Interest Group Proceedings: 2005 Sept. 12-15: Rapid City, South Dakota: U.S. Geological Survey.

Fahrenbach FV, Steece JF, Sawyer KA, McCormick GL, Schulz LD, Redden JA. 2010. South Dakota stratigraphic correlation chart: South Dakota Geological Survey, Oil and Gas Investigation 3. Accessed 11/14/2012. Available from: http://www.sdgs.usd.edu/pubs/pdf/ogi-03.pdf

Gerhard LC, Fischer DW, Anderson SB. 1990. Petroleum geology of the Williston Basin. In: Leighton MW, Kolata DR, Oltz DF, Eidel JJ, editors. American Association of Petroleum Geologists Memoir 51: Interior cratonic basins, Chapter 29, p. 507-559.

Gott GB, Wolcott DE, Bowles CG. 1974. Stratigraphy of the Inyan Kara Group and localization of uranium deposits, southern Black Hills, South Dakota and Wyoming: U.S. Geological Survey Professional Paper 763, 57 p.

Hamid H, Morozov IB, Kreis LK. 2004. Progress in seismic delineation of the southern margin of the Middle Devonian Prairie Evaporite Formation in the Elk Point Basin, south-central Saskatchewan. Summary of Investigations 2004, Volume 1. Saskatchewan Industry Resources, Miscellaneous Report 2004-1, Paper A-5: Saskatchewan Geological Survey.

Holter ME. 1969. The Middle Devonian Prairie Evaporite of Saskatchewan: Saskatchewan Department of Mineral Resources Report 123, 134 p. http://ir.gov. sk.ca/Default.aspx?DN=4602,4477,3440,3385,293 6,Documents (Accessed 11/14/2012).
Johnson KS. 1997. Evaporite karst in the United States, carbonates and evaporites, vol. 12, Issue 1, pp. 2-14.

Johnson KS, Gonzales S, Dean WE. 1989. Distribution and geologic characteristics of anhydrite deposits in the United States, in Dean, W.E., and Johnson, K.S., eds., Anhydrite deposits of the United States and characteristics of anhydrite important for storage of radioactive wastes, U.S. Geological Survey Professional Paper 1794, pp. 9-90.

LeFever JA. 2011. The Spearfish Formation - another unconventional target: North Dakota Geological Survey Newsletter. 38 (1): 11-14.

LeFever JA. 2012. Impact of the dissolution of the Devonian Prairie Salt in North-central North Dakota: North Dakota Geological Survey Newsletter: 39(2): 6-9.

LeFever JA, LeFever RD. 1995. Relationship of salt patterns to hydrocarbon accumulations, North Dakota Williston Basin. In: Hunter LDV, Schalla RA, editors. 7th International Williston Basin Symposium, Montana Geological Society, p. 69-88.

Orchard DM. 1987. Structural history of Poplar Dome and the dissolution of Charles Formation salt, Roosevelt County, Montana. In: Fisher DW, editor. Fifth International Williston Basin Symposium: 1987 14-17 June: Grand Forks, North Dakota. North Dakota Geological Survey. p. 159-177.

Palmer AN, Palmer MV. 2008. Field Guide to the Paleokarst of the Southern Black Hills. In: Sasowsky ID, Feazel CT, Mylroie JE, Palmer AN, Palmer MV, editors. Karst from Recent to reservoirs. Karst Waters Institute Special Publication 14. p. 189-220.

Parker JM. 1967. Salt solution and subsidence structures, Wyoming, North Dakota, and Montana: American Association of Petroleum Geologists Bulletin 51: 1929-1947.

Peterson JA. 1988. Geologic summary and hydrocarbon plays, Williston Basin, Montana, North and South Dakota, and Sioux Arch, South Dakota and Nebraska, U.S.: U.S. Geological Survey Open-File Report 87-450-N, 43 p.

Peterson JA. 1995. Williston Basin Province, in U. S. Geological Survey 1995 National Assessment of United States Oil and Gas Resources, Digital Data Series DDS-30, Release 2, CDROM. Accessed 11/14/2012. Available from: http://certmapper.cr.usgs.gov/data/noga95/prov31/ text/prov31.pdf 
Peterson JA, MacCary LM. 1987. Regional stratigraphy and general petroleum geology of the U.S. Portion of the Williston Basin and adjacent areas. In: Peterson JA, Longman MW, Anderson SB, Pilatzke RH, Kent DM, editors. 1987. Williston Basin, anatomy of a cratonic oil province: Rocky Mountain Association of Geologists, p. 9-43.

Rasmussen DL, Bean DW. 1984. Dissolution of Permian salt and Mesozoic syndepositional trends, central Powder River Basin, Wyoming. In: Thirty-fifth Annual Field Conference Wyoming Geological Association Guidebook, p. 281-294.

Sabel JM. 1984. Sedimentology and depositional history of the PermoTriassic Spearfish Formation, southwestern Black Hills, South Dakota, in Goolsby, Jim, and Morton, Doug, eds., The Permian and Pennsylvanian geology of Wyoming, Wyoming Geological Association, 35th Annual Field Conference Guidebook, p. 295307.

Sando WJ. 1995. Geologic history of salt beds and related strata in the upper part of the Madison Group (Mississippian), Williston Basin, Montana and North Dakota. U.S. Geological Survey Bulletin 2112, 51 pp.

Strahler AN, Strahler AH. 1987. Modern physical geography: Wiley \& Sons, New York, 544 p. 
176 NCKRI SYMPOSIUM 2 I3TH SINKHOLE CONFERENCE 